\title{
Basic assumptions for forest management and nature conservation from axiological, legal, and economic perspective
}

\author{
Janusz Czerepko ${ }^{1}$, Marek Geszprych ${ }^{2}$, Piotr Golos $^{1} \bowtie$ \\ ${ }^{1}$ Forest Research Institute, Sękocin Stary, Braci Leśnej 3, 05-090 Raszyn, Poland, phone: +48 227150604 , \\ fax +48 22 7150391, e-mail: P.Golos@ibles.waw.pl \\ ${ }^{2}$ Institute of Spatial Management and Housing, Targowa 45, 03-728 Warsaw, Poland
}

Every man is obliged to refrain from such initiatives or actions, which could bring harm to the natural environment, and since the whole flora plays an irreplaceable role in maintaining the balance of nature, which is indispensable for life in all dimensions, its conservation and respect becomes a particularly urgent need for people.

John Paul II, Zamość, June 12, 1999

\section{Abstract}

The subject matters of this article are mutual relationships between nature conservation and forest management, considered from the axiological and legal point, as well as the economic and social conditions of forest management.

\section{INTRODUCTION}

The subject matter of this article is the study of mutual relationships between nature conservation and forest management, considered from the axiological and legal point, as well as the economic and social conditions of forest management. Since the legal regulations related to the above subject matters are distributed throughout numerous legislative acts, and they are also the subject of interest of law enforcement authorities, the analysis has been limited to the issue of values in legal norms, related to nature conservation and forest management. Regarding the close association of presented problem with economic and social aspects of forest management, conditions accompanying practical performance of specified matters have also been presented.
Forest related regulations stipulate the specific manner of forest management, the purpose of which is to use thereof in such a manner so that there was no depletion of resources for future generations. The presented manner of forest management was recognized in the $18^{\text {th }}$ century by Hans Carl von Carlowitz in his work 'Sylvicultura oeconomica, oder haußwirthliche Nachricht Und Naturmäßige Anweisung zur Wilden BaumZucht', who indicated the sustainable forest management, in which as many trees are harvested as may grow again (Bukowski 2011). In Forest Act (Act of... 1991), such use of forests was specified as the permanently sustainable forest management, where an important place is given to nature conservation. The laws of Forest Act regulate the protection of forests (art. 1), although to a limited extent, as well as based on other values than 
the laws of Nature Conservation Act (Act of... 2004). The latter assumes that forests constitute the resource, on the preservation of which the existence of life on Earth depends in the long term, including the quality of man's life environment and health. In addition, Forest Act is the law that regulates economic aspects of forest functioning, which are necessary for maintaining anthropogenic forest resources with the participation of man who conducts forest management.

The work includes presentation of economic conditions accompanying the idea of nature conservation performed in forest areas, which should be taken into account with regard to axiological and legal arguments. The existing laws of Forest Act (art. 7 item 1), from the point of axiology and the regulations of the Constitution of the Republic of Poland, indicate proper sequencing of sustainable forest management purposes. However, business practice shows that their performance depends on the well-balanced use of forests, which does not exceed their production capabilities (art. 13 item 1 point 5), including wood harvesting, which enables its optimal functioning. The above regulation becomes particularly important in view of art. 50 item 1 of Forest Act, which states that State Forests run their activity based on the financial autonomy, and they incur their operational costs from their own revenues. The mentioned provision indicates that State Forests National Forest Holding (Państwowe Gospodarstwo Leśne Lasy Państwowe - PGLLP), could be treated as an enterprise, however, the circumstances in which PGLLP performs the multi-purpose management, not receiving any special purpose grant from the budget or any subsidy, make PGLLP constitute a specific public corporation with multiple obligations imposed on it by the legislator (Hausner and Żylicz 2014). The above does not change the fact that state forests were considered as an enterprise based on the provisions included in the regulation by the Minister of Forestry of December 27, 1949 on the organization and the scope of operation of state forests' enterprises (Journal of Laws No. 63, item 510) (Dz.U. $\mathrm{nr} 63$, poz. 510), and further based on regulation by the Minister of Forestry and Wood Industry of December 17,1959 , on the organization and the scope of operation of state forests' enterprises (Journal of Laws of 1960, No. 2, item 13) (Dz.U. z 1960 r., nr 2, poz. 13). It should also be noted that the term 'enterprise' is also used nowadays in the context of State Forests - the example of which is the parliamentary draft law on amendment of the Constitution of the Republic of Poland (print no. 2374), which states that 'forests which constitute the property of the State Treasury are managed based on self-financing by "State Forests" enterprise, pursuant to purposes set forth in art. 5 of the Constitution' (Report...). The above issues (used more or less consciously) do not change the real extent of public tasks performed by PGLLP, mainly related to non-productive functions of forests (public tasks financed from own funds are not performed by 'enterprises', which are stricte business entities).

One of the most important public functions is the preservation of nature; this idea is widely incorporated in programs of forest education in the society, mainly among children and young people. Both PGLLP's activities relate to the performance of the state's constitutional responsibilities, included in the performance of policy that ensures the ecological safety for today's and future generations (art. 74 item 1 of the Constitution of the Republic of Poland). The necessity for active forest management in the mentioned scope is confirmed in the social feeling expressed mostly in a declarative manner in public opinion surveys, and, which is unfortunately still rare, in real attitudes and behaviours.

\section{LEGAL, AXIOLOGICAL, AND ECONOMIC BASES FOR NATURE CONSERVATION AND FOREST MANAGEMENT}

Issues relating to the preservation of nature seen in the context of forest related problems have been regulated in multiple legal acts, mainly in Nature Conservation Act and Forest Act. In addition, the above issues are governed by the provisions of the following acts: Environment Protection Act (Act of... 2001), Act on the access to information on the environment and its protection, on the participation of society in environment protection, and on the environmental impact assessment (Act of... 2010), Act on the protection of agricultural and forest land (Act of... 1995), tax legislation, civil code, and in implementing acts to the mentioned regulations, as well as indirectly in other legal regulations (Act of... 2003). Frequently, EU directives and the provisions of international conventions constitute the basis for the introduction (transfer) of regulations in domestic provisions of 
law. In the context of EU regulations, it is necessary to emphasize that the EU acquis related to the environment protection is very abundant as it includes over 800 legislative acts of different status, out of which over 200 are directives. Some of them play a fundamental role in the enforcement of nature conservation in forests, in particular Council Directive 92/43/EEC on the conservation of natural habitats and of wild fauna and flora (OJ EU L 206, 22.7.1992 as amended) and Council Directive 79/409/EEC on the conservation of wild birds (OJ EU L 103, 25.04.1979 as amended).

Based on the above directives, the shape and size of Natura 2000 regions has been settled, where forests constitute $50 \%$ of area. In Poland, forest areas in NATURA 2000 sites constitute 33\% (Czerepko et al. 2013). At the same time, in Natura 2000 areas, Member States must warrant non-deterioration of species and habitats' protection because of human activity. It is important that every member state individually decides the manner of respecting these conditions. All nature protection activities must be carried out with regard to economic, social, and cultural, as well as regional and local conditions. Most frequently, minor changes need to be introduced to allow the coexistence of present day use of areas with the protection of present species and habitats. In all cases, it is important that local societies within Natura 2000 regions are involved in decisions related to the long-term management of these areas, beginning from private owners and users of lands, industry and associations aiming at nature conservation, through local self-governments, ending on the government administration. These issues are regulated in various legislative acts.

With such widespread legislative distribution of investigated issues, it is natural that not all regulations are fully consistent and compatible. However, legislators cannot be accused of not taking measures to standardize these issues related to nature conservation and forest management, which might seem difficult to reconcile. The example here are the following regulations: so-called assessment act (Act on access to... 2008), Regulation of the Council of Ministers of November 9, 2010 on projects which may significantly affect the environment, as well as new regulations regarding the nature conservation. A connection link between the nature conservation and forest management is undoubtedly the constitutional regulation related to ensuring the environment protection with regard to the principle of sustainable development (art. 5 of the Constitution of the Republic of Poland). The above principle constitutes an example of a program framework setting the state's objective to be the environment protection in correlation with the permanently sustainable forest management. Art. 74 of the Constitution of the Republic of Poland is also the binder between forest management and nature conservation, since it relates to the environment protection and the principle of subsidiarity. The above regulation imposes an obligation on public authorities to protect environment through 'pursuing of the policy which ensures ecological safety for current and future generations, and supporting citizens' actions in order to protect and improve the condition of environment. As a result, the public authorities are obliged to support actions by single citizens, established forest associations, and other organizational structures operating in the forestry, provided that those entities carry out forest management focusing particularly on the protection objective. At the same time, it results from the above rule of law that every single person is obliged to comply with the rules of nature conservation, including in-forest areas. Words by Pope John Paul II, uttered during one of his visits to Poland, included at the beginning of this article are the essence of the above principle.

The issues of nature conservation and forest management were combined in the provisions of the Act on preservation of the national character of strategic natural resources of the country (Act on the preservation... 2001), classifying state forests and nature resources of national parks as strategic natural resources of the country (art. 1 item 3 and 5). The provisions of the above act indicate that the management of strategic natural resources is carried out in compliance with the principle of sustainable development in the interest of general (society) good (art. 3) and, in order to achieve the above objective, relevant public authorities and other entities, performing, based on separate provisions of law, the management activities on specified natural resources, are obliged to maintain, increase, and improve renewable resources, pursuant to the principle of sustainable development. The above regulation must not surprise, if values provided by forest ecosystem are taken into account. Undoubtedly, all protective roles need to be mentioned here, including water, soil, air, or nature resources. Such broad approach to many various 
usability features provided by forest enables the definition of so called intrinsic value of forest (Hausner and Żylicz 2014). This value cannot be defined in economic terms, but it comprises various use values of forests, both measurable and quantifiable material goods, as well as non-material services, for which the results of evaluation and value pricing still cause controversy, and there is still no consent as to their inclusion in macroeconomic indicators, of the country, continent, and the whole world (green economy).

The improvement of quality and quantity, and even the maintenance of various values of forests and forest management require relevant financial outlays (costs), which are most frequently not related to any revenues. This is because the specified utilities are predominantly positive external effects of forest management with common good features. Due to this, the foresters' work is described as public service, although it is financed through the sale of wood raw material. The mentioned obligations related to forest management must be performed in such a manner that revenues from the sale of wood should enable payments of not only the direct costs of nature conservation, but also alternative costs or the reimbursement of losses caused by the use of natural resources by man.

The financing of social and protective features, including nature conservation by forest management, is not only a necessity related to the performance of legal obligations, which were established due to the common intrinsic value of forest ecosystem, but also the response to expectations expressed by the society towards entities dealing with the management of natural resources. This is confirmed by the results of the public opinion survey regarding Natura 2000 areas. The determined level of awareness regarding the matter differed significantly among investigated countries. The percentage of people, who had never heard about Natura 2000, ranged from $19 \%$ in Finland to $97 \%$ in Ireland and Great Britain. The awareness of what Natura 2000 exactly is was the maximum in Finland (41\%) and Bulgaria (38\%). Among the countries where over half of the citizens had heard about Natura 2000 were Estonia (59\%), Slovenia (55\%), Greece (53\%), and Poland (51\%). In almost all investigated countries, apart from Finland and Bulgaria, there were more people who had just heard about Natura 2000 than those who could

Table 1. Social preferences regarding selected non-productive functions of forests determined in research by Forest Research Institute

\begin{tabular}{|c|c|c|c|c|c|c|c|}
\hline \multirow[b]{2}{*}{ Forest Functions } & \multicolumn{7}{|c|}{ Research Site and Year } \\
\hline & $\begin{array}{l}\text { OBOP } \\
(2000)\end{array}$ & $\begin{array}{c}\text { LKP Lasy } \\
\text { Janowskie } \\
(2002)\end{array}$ & $\begin{array}{c}\text { LKP Lasy } \\
\text { Beskidu } \\
\text { Śląskiego } \\
\text { (2002) }\end{array}$ & $\begin{array}{c}\text { LKP Lasy } \\
\text { Oliwsko- } \\
\text { Darżlubskie } \\
\text { (2002) }\end{array}$ & $\begin{array}{l}\text { Urban } \\
\text { forests } \\
\text { in Łódź } \\
(2004)\end{array}$ & $\begin{array}{l}\text { RDLP in } \\
\text { Cracow } \\
(2005)\end{array}$ & $\begin{array}{c}\text { LKP } \\
\text { Warsaw } \\
\text { Forests } \\
(2006)\end{array}$ \\
\hline 1 & 2 & 3 & 4 & 5 & 6 & 8 & 7 \\
\hline 1) air protection & 27.9 & 29.7 & 27.9 & 29.0 & 27.2 & 21.6 & 28.5 \\
\hline $\begin{array}{l}\text { 2) forest as a living environ- } \\
\text { ment of plants and animals }\end{array}$ & 24.3 & 20.2 & 21.1 & 23.1 & 24.7 & 26.8 & 30.4 \\
\hline $\begin{array}{l}\text { 3) forest as a place of } \\
\text { recreation and relaxation }\end{array}$ & 11.7 & 15.1 & 13.6 & 15.5 & 15.3 & 12.9 & 15.9 \\
\hline 4) water conservation & 11.5 & 13.2 & 12.7 & 12.0 & 13.8 & 13.5 & 8.1 \\
\hline 5) forest vs. climate & 13.4 & 12.3 & 14.8 & 10.8 & 10.0 & - & 9.4 \\
\hline 6) soil conservation & 10.9 & 9.3 & 9.5 & 9.2 & 8.7 & 9.0 & 7.3 \\
\hline $\begin{array}{l}\text { 7) forest as a supplier of wood } \\
\text { raw material }\end{array}$ & - & - & - & - & - & 8.9 & - \\
\hline $\begin{array}{l}\text { 8) forest as a place of collecting } \\
\text { fruit and fungi }\end{array}$ & - & - & - & - & - & 7.2 & - \\
\hline 7) other, what? & 0.3 & 0.1 & 0.2 & 0.4 & 0.3 & - & 0.3 \\
\hline
\end{tabular}

Source: P. Gołos, Social role of forest public functions - model of a stand and forest desirable for recreation and relaxation. Leśne Prace Badawcze 2010 Vol. 71 (2), p. 149-164. 
explain what this term exactly referred to. The lowest level of awareness about Natura 2000 was amongst English, Irish, and Italian people. The European people's understanding of the role of protected areas is also worth mentioning. Most respondents (53\%) thought that the most important role of protected areas is the conservation of endangered plant and animal species. Countries with the strongest support for this viewpoint were Luxemburg and Germany. The next most important role mentioned was the prevention of destruction of valuable aquatic and terrestrial areas (43\%) - the most significant one for Finland and Great Britain, as well as the role of nature in ensuring access to clean water and air (38\%), which was indicated by Hungarians and Lithuanians. Spanish and Slovenian citizens mainly indicated the promotion of environment friendly use of land (24\% of the entire EU). Only $11 \%$ of respondents indicated environment friendly tourism and recreation, and these were mainly citizens of Germany, Belgium, and Ireland (Report 2010). Similar social surveys conducted at the Forest Research Institute (Instytut Badawczy Leśnictwa - IBL) on sample groups of people relaxing in forests indicate similar elements which are in the centre of social interest. The function of forest as an environment for plants and animals' living was indicated as the second most important forest benefit by different sample groups, and air protection role being mentioned as the most important benefit.

\section{Place of forest management AND NATURE CONSERVATION REGULATIONS IN THE LEGAL SYSTEM}

Both, regulations related to nature conservation, and forest management regulations are a part of the broader field, i.e., the environment protection law. Forest regulations mainly include the specific manner of forest ecosystems' management; its main objective is to control the use of forest ecosystem and see to it that overuse does not cause their depletion, which might lead to a situation that there is less forest ecosystem available for the future generations or it is available in worse quality. The provisions of Forest Act describe such a model of use as the permanently sustainable forest management (art. 6 item 1 point 1a) (Act of... 1991). A similar approach was applied to the management of hunting re- sources (Act of... 1995), fishing resources (Act on fisheries... 1985), or water resources (Water Law Act 2001). This means that the laws of Forest Act, similar to the laws of abovementioned acts, govern the management of resources of one kind - forest resources (Geszprych and Borowiak 2011). In the doctrine related to the environment protection law, the provisions of the abovementioned acts are described as 'sectional'. Therefore, the environment protection act should be named as 'integrating' and 'bonding' the 'sectional' regulations in the scope of protection of all the environment components (land, water, forests, fish, animals, etc.), since it deals with them 'however from a certain angle of their particular values' (Radecki 2008). Another reason for such an approach is the concept of environment protection law and the nature conservation law presented by J. Sommer (2006). According to the author, "the environment protection law refers to the rules of law that regulate human's impact on the environment in order to prevent negative effects, and in particular, a threat to human's health and life. The environment protection law is the rule of law governing human's behaviours to prevent unfavourable alterations of nature. However, the unfavourable alteration does not have to relate to the protection of human's health and life'. As regards the so called 'sectional' rules of law, another role may be noticed. Namely, the provisions of the nature conservation act formulate the conservation rules of such nature resources which are distinguished for their unique natural features, including the ones endangered with extinction.

In conclusion, it should be indicated that the nature conservation law may be relatively separated from the environment protection law. This approach is additionally supported by a distinction made in the legal doctrine of separate institutions dealing with nature conservation law in the scope of institutions dealing with the environment protection law (Habuda and Radecki 2010). Adopting, as the principal point of reference, the preservation of natural heritage, including forest assets, the norms included in the provisions of the nature conservation act are the special provisions with reference to other regulations in the scope of the environment protection law, mainly so called 'sectional' rules of law, including the forest act. As it is indicated in the subject literature, should there be a concurrence of the above regulations, the provisions of the nature conservation law should prevail (Geszprych and Borowiak 2011). 
The above considerations are appropriate, if we assume that the primary objective is preservation of natural assets. However, the preservation of natural assets is not always the primary objective, which shall be discussed in the following part of this article.

\section{Convergence of nature CONSERVATION AND FOREST MANAGEMENT OBJECTIVES}

Many aspects of provisions of the forest act converge with the environment protection objectives set forth in the environment protection act. These common objectives include, among others: preserving biodiversity, ensuring the continuity of plant, animal, and fungi species, along with their habitats, through their maintenance or restoration to the proper protection level, and maintaining or restoring the proper protection of nature habitats, as well as other resources, formations, and nature components - specified in the nature conservation act (art. 2 item 1 of Nature Conservation Act) (Act of... 2004). The above scope includes the rules of maintenance, preservation, and extension of forest resources, and the principles of forest management in relation to other elements of the environment (art. 1 of Forest Act). Forest management principles also refer to the nature conservation (art. 8 of Forest Act). These are the following principles: general protection of forests, durability of forest maintenance, continuity and sustainable use of all forest functions, as well as the extension of forest resources. The convergence of nature conservation and forest management objectives was outlined in the provisions regarding the performance of permanently sustainable forest management, and considering the terms set forth in regulations on nature conservation in forests by the forest management, which constitute nature reserves, and forests comprising national parks (art. 7 of Forest Act).

The nature conservation objectives are also referred to in the obligations of forests' owners related to the general protection of forests specified in art. 9 item 1 of Forest Act, as well as in the scope of durable maintenance of forests and ensuring the continuity of their use set forth in art. 13 item 1 of Forest Act. The above scope also includes fighting and protective interventions, should harmful organisms occur, set forth in art. 10 of Forest Act. The above purposes are also reflected in the rules for the recognition of forests as protective ones, set forth in art. 15-17 of Forest Act, establishing promotional forest areas as referred to in art. 13b of Forest Act, as well as obligations related to the permanently sustainable forest management, included in art. 13a of Forest Act. It should be mentioned that State Forests, in the performance of the above tasks, initiate, coordinate, and carry out the periodical evaluation of the condition of forests and forest resources, and forecast changes in forest ecosystems; they develop periodical large-area inventories of forests condition, update forest resources' condition, and they also hold a database of forest resources and forests' condition.

Similar measures to ensure general and specific conservation of nature have been included in the nature conservation act (see art. 15, 18-22 of Nature Conservation Act). These are additional restrictions in forest resources management in active protection areas, in national parks, and nature reserves (the use of such areas should be subject to protective interventions described in the conservation plan or conservation tasks) until the complete withdrawal from the use of strict protection areas. Additionally, in order to ensure the protection of these areas, the legislator introduced an obligation to agree with the regional director for the environment protection of, among others, the project of forest management plan and a simplified forest management plan in a part related to the buffer zone, as relates the settlements of those plans or tasks, which may have a negative impact on the conservation of nature in the national park or on the nature reserve preservation purposes. Drafts of the last two documents must also be agreed in a part related to a national park (see art. 10 item 7 and 8 , and art. 13 item $3 \mathrm{~b}$ of Nature Conservation Act). Similar restrictions are also applied with reference to the species conservation.

In addition, in the nature conservation act, the legislator formulated detailed praxeological directives (set forth in art. 2-4 of Nature Conservation Act) considering the specifics of this regulation, based on settlements included in Nature Conservation Strategy (Sommer 2006). These are, among others, obligatorily nature protection in business activity, and the common obligation of compliance therewith by all law entities, which means that a forest management plan should include a nature conservation program. This is conformed in legal regulations related to the nature conservation, 
which indicate the nature protection program to be a part of a forest management plan including an overall description of nature condition, tasks related to its conservation, and measures to achieve them, covering the territorial range of forest division (art. 6 item 1 point 11 of Nature Conservation Act). These programs fulfil different objectives in forestry, such as: 'the improvement of preservation conditions, enrichment of natural resources, and maintaining biodiversity in forests (level of species, population, ecosystem, and landscape)'; 'documenting and imaging natural features and threats to nature in the division', 'prioritizing groups of functions of individual forest areas'; 'the indication of further sites to be covered by particular forms of protection and provisional settlement of subjects and purposes, as well as the protection methods', and 'the improvement of forest management and nature conservation with the full use of soil and habitat works (Miś 2002).

It should also be noted that the State Forests receive special purpose subsidies from the state budget, among others, for the development and protection of forests in case of any threat to their durability, as well as for the development of conservation plans for nature reserves under the State Forests' management, their execution, species-specific protection of fauna and flora, and the supervision over the areas comprising Natura 2000 sites (art. 54 item 3 and 5 of Forest Act). The performance by State Forests of forest education tasks (specified in art 54 item 6 of Forest Act), which refer to establishing and running forest promotion centres, and creating nature and forest trails, also contributes to the nature conservation.

The mentioned actions result in specific economic consequences for forest management, particularly in circumstances in which subsidies from the state budget have decreased since 2008 from 20-30 million PLN annually to only 4-5 million PLN, with the increase of forest management expenditure for nature conservation, or the constant increase of spending on the maintenance of education centres, and the costs of forest cleaning from PLN 21 million in 2010 to over PLN 31 million in 2013 (Financial Statement... 2008-2013). Based on IBL's research in the years 2005-2009, in RDSF $(R D L P)$ in Katowice, the total unit costs of the execution of certain non-production functions of forest ranged from 120 $\mathrm{PLN} / \mathrm{ha}$, and almost $14 \mathrm{PLN} / \mathrm{m}^{3}$ of wood harvested as per the plan, including the nature conservation costs respectively as above $10 \mathrm{PLN} / \mathrm{ha}$ and $1 \mathrm{PLN} / \mathrm{m}^{3}$ of harvested wood.

The convergence of nature conservation and forest management objectives was also outlined in penal provisions related to certain behaviours in forests includ-

Table 2. Costs related to bird conservation and other nature conservation costs (in thousands PLN) incurred in the years 2005-2009 by RDSF forest divisions in Katowice

\begin{tabular}{|c|c|c|c|c|c|c|c|}
\hline \multirow{2}{*}{$\begin{array}{l}\text { Interventions related to bird conservation and nature } \\
\text { conservation }\end{array}$} & \multicolumn{6}{|c|}{ Costs in years [in thousands PLN] } & \multirow{2}{*}{$\%$} \\
\hline & 2005 & 2006 & 2007 & 2008 & 2009 & Total & \\
\hline Hanging nesting boxes & 170 & 151 & 199 & 218 & 196 & 936 & 31.42 \\
\hline Maintenance of nesting boxes & 215 & 221 & 313 & 382 & 302 & 1421 & 47.70 \\
\hline Bird feeding & no data & 159 & 140 & 145 & 176 & 622 & 20.88 \\
\hline Total costs of bird conservation & 385 & 531 & 652 & 745 & 674 & 2979 & 100.00 \\
\hline Animal species protection in State Forests & 257 & 361 & 473 & 527 & 504 & 2122 & 43.07 \\
\hline $\begin{array}{l}\text { Fencing anthills and fencing maintenance, costs of } \\
\text { interventions in other protected sites }\end{array}$ & 17 & 23 & 19 & 21 & 2 & 84 & 1.70 \\
\hline $\begin{array}{l}\text { Establishing and maintenance of tree clusters, interventions } \\
\text { in reserves, hanging and maintenance of bat shelters }\end{array}$ & 9 & 12 & 25 & 46 & 165 & 258 & 5.24 \\
\hline Other nature conservation costs & 284 & 396 & 517 & 593 & 671 & 2463 & 49.99 \\
\hline Total nature conservation costs & 567 & 792 & 1034 & 1187 & 1342 & 4927 & 100.00 \\
\hline Total & 952 & 1323 & 1686 & 1932 & 2016 & 7906 & 100.00 \\
\hline
\end{tabular}

Source: P. Gołos, Costs related to the provisioning of non-production forest management functions based on an example of the Regional Directorate of State Forests in Katowice. Forest Research Papers (Leśne Prace Badawcze) 2012 Vol. 73 (3), p. 209-220. 
ed in the Penal Code (art. 181, 187, and 188) (Code... 1997) and the Violations Code (Section 19, Forest, field, and garden damaging (art. 148-166) (Code 1971). The above objectives were also regulated in many other material provisions, which are all difficult to mention in this paper.

\section{Conflict of values and divergence OF INTERESTS - DEADLOCK OR ACTION?}

The above considerations pertained only to the points of convergence, not the splitting points between forest management and nature conservation. However, the situation is not always so clear as to prove the primacy of nature related purposes over non-nature objectives. Sometimes, other out-of-environment values turn more important, and their execution is important for the achievement of common good. Such situation results in mutual collisions of norms and values between nature conservation and forest management. This is the case of necessity to remove trees or shrubs which prevent the visibility of signalling and trains or the operation of railway equipment or cause snowdrifts, referred to in the provisions of the railway act (art. 56). Similarly, if a forest tree stand, which grows in the border zone, prevents the visibility of the country border or border signs, it should be removed, which is referred to in the provisions of act on the protection of state border (art. 11). Pursuant to the provisions of the act on developing and implementing nuclear energy projects and related facilities - in a permit for the construction of nuclear energy facility, the governor consents for the removal of trees or shrubs growing on properties covered by a decision on the determination of location for the investment in the scope of building a nuclear energy facility (art. 16-17). Based on the provisions of the act on special terms for the preparation and implementation of public road investments, laws regarding the protection of agricultural and forest grounds do not apply to the agricultural and forest lands covered by decisions permitting the performance of road investment (art. 21 item 1). Further, pursuant to the provisions of the act on supporting the development of telecommunications networks and services, in a permit for the construction of regional broadband network, the governor allows - in the scope necessary for the performance of investment
- for the removal of trees or shrubs growing on properties covered by a decision on the determination of location for the regional broadband network investment (art. 61).

Other cases relating to actions, which do not lead to the performance of permanently sustainable forest management, have an economic and business basis. For instance, pursuant to the binding legal regulations and the settled course of court and administrative decisions, a farmer whose farm was completely damaged and who is now in a very difficult financial situation, may request the head of the local authority supervising the forest management in the forest to issue a decision authorizing the farmer to harvest wood contrary to the simplified plan of forest development or an inventory decision (referred to in art. 19 item 3 of Forest Act).

The best course of action that should be taken in the circumstance when the whole tree stand is dominated by root-rot fungus or insects, such as bark beetle, is questionable. From the point of nature, the invasion of root-rot fungus or harmful insects in a tree stand may be beneficial, because they contribute to the functioning and maintaining the continuity of natural processes (e.g., they stimulate natural renewals or contribute to the increase of biodiversity) (Sokołowski 2002). However, for forest management, they constitute serious damage and involve the risk of destroying large areas in a tree stand. The removal of the above tree stand will indirectly contribute to maintaining permanently sustainable forest management in the long term.

The conflict of values in the forestry mainly refers to the choice between the value of business activity freedom and the environment protection. For example, PGLLP manages in the area where the resources of economic goods determine the execution of many public benefit goods. The first mentioned above are governed by the market, the second are outside the market, which may cause conflicts due to the necessity to cover the first ones with protective actions and to decrease their market potential. The second mentioned above benefit as a result of this, which does not have anything in common with the market mechanism. As far as it is possible to settle the amount and structure of demand and supply, they can no longer be the subject of market exchange, and they are not the source of forest management revenues. Balancing these relations to retain the interest of an individual entity (including forest enter- 
prises), as well as the society, is a significant problem of the current direction of forest management. The law is attempting to find methods to reconcile these discrepancies by giving an explicit priority to certain values at the expense of the other (which does not bring good results most often), or by trying to assign such meaning to the values, due to which discrepancies are brought to the minimum level or fade away (e.g., the introduction of forest management durability principle), or by creating methods to reach a compromise (the principle of proportionality). An important issue is that arising conflicts should always be solved with the priority given to more valuable aspects (Cieślak 2010).

The above arguments indicate that the thesis regarding the specific character of nature conservation regulations in relation to the provisions of Forest Act, emphasized at the beginning of the subject paper in the context of nature, is not always obvious. At the same time, an important matter is to find an appropriate balance between nature conservation, as the national heritage, and the rules of economy, which do not always have to or should give way to falsely adopted assumptions related to the conservation. In order to undertake effective decisions in the above scope, an owner (manager) should have the knowledge of what values are at his disposal. As far as there is no great difficulty in settling the value of market goods (it is commonly accepted that it is a market price), the problematic issue is still the utilization and the acceptability of results of non-market goods' pricing. The recognition of impartial values of the full set of forest goods and benefits, as well as forest management, determines not only the appropriateness of business decisions, but it is also the basis for shaping forest related policy, whose law is a basic tool.

\section{SUMmARY AND FINAL COMMENTS}

Forests, as the public good, should be used in a manner that corresponds to social, cultural, and aesthetic values acknowledged in a given society. Laws must be established along with their enforcement methods to ensure ethical use of forests, which is concisely reflected in sustainable development paradigms: the form of social and economic development, an intergenerational concept, a process integrating all human's ac- tions, leading to the highest possible equalization of possibilities related to the satisfaction of all people on the planet. It is therefore significant in the activity of all entities operating in the forest sphere to mitigate conflicts arising out of attempts by individuals, local societies, and other groups of interest, regarding the intention to locate residential buildings, perform priority investments of great economic and political importance, in the areas where nature is attractive, and as a result of formulating extreme and unrealistic demands by environmentalists.

At the same time, it must not be forgotten that the implementation of permanently sustainable forest management constitutes the value which is to contribute to the satisfaction of current and future generations' needs. It is the man, who is the recipient of all goods and benefits of forest and forest management, and who, by 'cooperation' with nature, makes these values real. This fact should be taken into account in forest management planning, because such management must not be carried out in isolation from the surroundings in which the forest is operating. Nevertheless, it should be noted that although the Council of Ministers adopted the Strategy for the sustainable development of rural areas, agriculture and fisheries, in April 2012 for the years 2012-2020, a few months later the National Development Strategy 2020 (Strategy... 2012), and then the Action Plan for the execution of the National Spatial Development Concept 2030 (Concept... 2013), none of the above documents indicate forests as a strategic element or a development tool of the country (where forests of different ownership cover almost $1 / 3$ of surface), or even as a tool in spatial planning or development. Neither of them contain separate tasks for forest management and forests (Degórski 2014). The above proves that even though the value of forest conservation leading to the preservation of common good is extremely important, not all are aware of this significance. The lack of understanding for the role and importance of forest management (due to multiple public benefits) is confirmed by not a very prudent decision on the necessity to pay a contribution to the State budget in the amount of PLN 1.6 billion in the years 2015-2016, as well as an obligation to pay $2 \%$ of revenues from the sale of wood (art. 58a of Forest Act). The above unfavourable events, which fortunately did not manage to destabilize the PGLLP's financial situation, and therefore negative social or nature consequences 
were avoided (due to the maintenance of constant demand for wood), resulted in the more extensive search for solutions consolidating the public character of the state forests.

\section{References}

Bukowski Z. 2011. Zrównoważony rozwój a gospodarcze korzystanie z zasobów przyrodniczych. In: Prawo Ochrony Przyrody a Wolność Gospodarcza (ed.: M. Górski). Polskie Zrzeszenie Inżynierów i Techników Sanitarnych Oddział Wielkopolski, Łódź-Poznań.

Cieślak Z. 2010. Status ontologiczny wartości w prawie (zarys problemu). In: Wartości w planowaniu przestrzennym (eds.: Z. Cieślak, A. Fogel). Wyd. Instytut Gospodarki Przestrzennej i Mieszkalnictwa, Warszawa.

Czerepko J., Gawryś R., Cieśla A., Sokołowski K., Wróbel M., Gryz J., Hilszczański J., Jaworski T., Kalinowski M., Korzybski D., Mionskowski M., Paluch R., Pierzgalski E., Pigan I., Plewa R., Rachwald A., Zin E., Harnist S. 2013. Ramowe zasady prowadzenia gospodarki leśnej na obszarach Natura 2000. IBL, Sękocin Stary.

Degórski M. 2014. Infrastrukturalna wartość lasów: lasy w zagospodarowaniu przestrzennym i kształtowaniu krajobrazu; społeczno-kulturowe wartości lasu w przestrzeni (w środowisku życia człowieka). In: Lasy jako czynnik... (eds.: P. Gołos, A. Kaliszewski, K. Rykowski). IBL, Sękocin Stary.

Geszprych M., Borowiak M. 2011. Ochrona przyrody i gospodarka leśna - współzależności prawno-aksjologiczne. Kontrola Państwowa, 5, 94-95.

Gołos P. 2010. Społeczne znaczenie publicznych funkcji lasu - pożądany dla rekreacji i wypoczynku model drzewostanu i lasu. Leśne Prace Badawcze, 71 (2), 149-164.

Habuda A., Radecki W. 2010. Instytucje prawa ochrony przyrody. In: Instytucje prawa ochrony środowiska (ed. W. Radecki). Difin, Warszawa, 204-230.

Hausner J., Żylicz T. 2014. Aksjologiczne podstawy i systemowo-ekonomiczne reguły racjonalnej gospodarki i polityki leśnej. Panel ekspertów „Rozwój”. Lasy i gospodarka leśna jako instrumenty ekonomicznego i społecznego rozwoju kraju w projekcie
Narodowy Program Leśny. Instytut Badawczy Leśnictwa, Sękocin Stary, http://www.npl.ibles.pl/ sites/default/files/referat/referat_j.hausner_t.zylicz. pdf.

Iwańska B. 2008. Postępowanie w przedmiocie wydania „decyzji o środowiskowych uwarunkowaniach” - dylematy interpretacyjne. In: Wspólnotowe prawo ochrony środowiska i jego implementacja w Polsce trzy lata po akcesji (eds.: J. Jendrośka, M. Bar). Wrocław, 208.

Miś R. 2002. Program ochrony przyrody w urządzaniu lasu. In: Zadania gospodarcze lasów a funkcje ochrony przyrody. Materiały z VII Sympozjum Ochrony Ekosystemów Leśnych, Wyd. SGGW, Warszawa, 127-136.

Report: Attitudes of Europeans towards the issue of biodiversity. Analytical report, Wave 2, opublikowany w marcu 2010 r., www.ec.europa.eu/ public_opinion/flash/fl_290_en.pdf, streszczenie: www.ec.europa.eu/public_opinion/flash/fl_290_ sum_en.pdf [12.02.2013].

Radecki W. 2008. Ustawa o ochronie przyrody. Komentarz. Difin, Warszawa.

Sokołowski A. 2002. Wpływ kornika drukarza na skład zbiorowisk leśnych w Puszczy Białowieskiej. Prace Instytutu Badawczego Leśnictwa, Ser. A, 1, 17-30.

Sommer J. 2006. Przedmiot prawa ochrony przyrody. In: Teoretyczne podstawy prawa ochrony przyrody (ed.: W. Radecki). Wyd. Prawa Ochrony Środowiska, Wrocław, 70-71.

Sommer J. 2006. Zasady ogólne i pojęcia niedookreślone w prawie ochrony przyrody. In: Teoretyczne podstawy prawa ochrony przyrody (ed.: W. Radecki). Wyd. Prawa Ochrony Środowiska, Wrocław, 98.

\section{Source}

Konstytucja Rzeczypospolitej Polskiej z dnia 2 kwietnia 1997 r. (Dz.U. nr 78, poz. 483 ze zm.).

Sprawozdania finansowo-gospodarcze PGL LP za lata 2008-2013. Dyrekcja Generalna Lasów Państwowych, Warszawa 2014.

Ustawa z dnia 20 maja 1971 r. Kodeks wykroczeń (Dz.U. z 2015 r., poz. 1094 ze zm.).

Ustawa $z$ dnia 18 kwietnia 1985 r. o rybactwie śródlądowym (Dz.U. z 2015 r., poz. 652).

Ustawa z dnia 12 października 1990 r. o Straży Granicznej. (Dz.U. z 2016 r., poz. 1643). 
Ustawa z dnia 28 września 1991 r. o lasach (Dz.U. z 2015 r., poz. 2100 ze zm.).

Ustawa z dnia 13 października 1995 r. Prawo łowieckie (Dz.U. z 2015 r., poz. 2168 ze zm.).

Ustawa z dnia 6 czerwca 1997 r. Kodeks karny (Dz.U. z 2016 r., poz. 1137).

Ustawa z dnia 27 kwietnia 2001 r. Prawo ochrony środowiska (Dz.U. z 2016 r., poz. 672 ze zm.).

Ustawa z dnia 6 lipca 2001 r. o zachowaniu narodowego charakteru strategicznych zasobów naturalnych kraju (Dz.U. nr 97, poz. 1051 ze zm.).

Ustawa z dnia 18 lipca 2001 r. Prawo wodne (Dz.U. z 2015 r., poz. 469).

Ustawa z dnia 16 kwietnia 2004 r. o ochronie przyrody (Dz.U. z 2016 r., poz. 2134 ze zm.).

Ustawa z dnia 27 marca 2003 r. o planowaniu i zagospodarowaniu przestrzennym (Dz.U. z 2016 r., poz. 778 ze zm.).
Ustawa z dnia 28 marca 2003 r. o transporcie kolejowym (Dz.U. z 2016 r., poz. 1727).

Ustawa z dnia 10 kwietnia 2003 r. o szczególnych zasadach przygotowania i realizacji inwestycji w zakresie dróg publicznych (Dz.U. z 2015 r., poz. 2031 ze zm.).

Ustawa z dnia 3 października 2008 r. o udostępnianiu informacji o środowisku i jego ochronie, udziale społeczeństwa $\mathrm{w}$ ochronie środowiska oraz o ocenach oddziaływania na środowisko (Dz.U. z 2016 r., poz. $353 \mathrm{ze} \mathrm{zm}$.).

Ustawa z dnia 7 maja 2010 r. o wspieraniu rozwoju usług i sieci telekomunikacyjnych. (Dz.U. z 2016 r., poz. 1537 ze zm.).

Ustawa z dnia 29 czerwca $2011 \mathrm{r}$. o przygotowaniu i realizacji inwestycji w zakresie obiektów energetyki jądrowej oraz inwestycji towarzyszących (Dz.U. nr 135, poz. 789 ze zm.). 